\title{
New data on the distribution of dwarf ephemeral wetland vascular plant species and communities in western and north-western Poland
}

\author{
Agnieszka Popiela ${ }^{1 *}$, Bożena Prajs ${ }^{1} \&$ Andrzej Łysko ${ }^{2}$
}

\author{
${ }^{1}$ Department of Botany and Nature Conservation, University of Szczecin, Felczaka 3c, 71-412 Szczecin, Poland, *e-mail: \\ popiela@univ.szczecin.pl \\ ${ }^{2}$ Department of Environment Protection and Development, West Pomeranian University of Technology, al. Piastów 17, 17-310 Szczecin, \\ Poland
}

\begin{abstract}
New phytosociological data are provided on Eleocharito-Caricetum bohemicae occurring on the easternmost range border in Central Europe. The distribution maps of selected character species of Eleocharito-Caricetum in Central Europe are presented.
\end{abstract}

Key words: Elatine triandra, Elatine hexandra, Eleocharis ovata, Carex bohemica, Eleocharito-Caricetum bohemicae, IsoëtoNanojuncetea, distribution, Central Europe

\section{Introduction}

Ephemeral species of wetland habitats (IsoëtoNanojuncetea) are components of the vegetation of Poland of considerable interest from the phytogeographic and ecological point of view. They are mainly annual taxa visible on the ground surface only through a certain part of the year, taking up habitats which are waterlogged or flooded through a part of vegetation season, their ranges are of disjunctive character, with most of them occurring in Central Europe on the periphery of their distribution. These plants occur as the first stage of succession on wet, periodically flooded ephemeral habitats. High lability of habitats results in a short vegetation period in species of this group and a time period from germination to giving out seeds being limited to two months.

The species under discussion form communities that are almost completely deprived of taxa of other ecological groups. They occur all over the world, while the centre of diversity of the species forming them is found in regions being characterised by the Mediterraneantype climate. Outside Europe, they represent communities which, in principle, are poorly known both with respect to differences and floristic composition (see
Brullo \& Minisalle 1998; Deil 2005). In Central Europe, they occur mainly in the western and central part of the continent.

The present paper aims at the presentation of new data providing insight into ephemeral wetland vegetation of Isoëto-Nanojuncetea in western and northern Poland in view of Central European maps presenting their characteristic species distribution range.

\section{Methods}

Phytosociological relevés according to the method of Braun-Blanquet were prepared in June and July 2005. Distribution maps for respective characteristic species were made by one of the authors (A. P.) based on the distribution range maps published and all available data from Central Europe (among others Haeupler \& SCHÖNFELDER 1988; SlaVík 1990; BenKERT et al. 1996; Lampe 1996; Popiela 2001; FuKareK \& Henker 2006; Biodiversity occurrence data provided by: GBIF-Sweden, Bundesamt fuer Naturschutz/Netzwerk Phytodiversitaet Deutschland, Finnish Museum of Natural History (Accessed through GBIF Data Portal, www.gbif.net, 2009-03-15). Species nomenclature was adopted after MiReK et al. 2002. 


\section{Results and discussion}

Phytosociological relevés nos. 1-11 listed in Table 1 were made on a drained bed of fish ponds in the vicinity of Łęknica (Lubuskie Province). Relevés 1-7 (Table 1) show a community with Elatine hexandra (pond in Janikowo), whereas relevés 8-11 (Table 1) present a community with Eleocharis ovata and Carex bohemica (pond in Brody). Relevés 12-19 (Table 1) document a community with Elatine hydropiper which developed on a water-deprived bed of Lake Kwiecko (Western Pomeranian Province).

The patches documented should be classified into the Eleocharo-Caricetum bohemicae Klika 1935 (syn. Eleocharetum ovatae) plant assemblage that reaches the absolute north-eastern limits of its home range (PoPIELA 2005). The Eleocharo-Caricetum bohemicae is an association with the north-western type of the distribution range in Europe. Most phytosociological data come from the area of Germany (BRULlo \& MinISALle 1998). Its patches are rarely observed in the north-western Poland with most known phytosociological materials coming from the southern and south-western part of the country (Fig. 1, see also Popiela 1997). In Poland, Eleocharito-Caricetum bohemicae shows a similar floristic composition as in the centre of its syntaxonomic distribution range, although it seems to be narrower with respect to the floristic composition and habitat. Patches are usually fragmented, containing often only one or two characteristic taxa (Popiela 1997).

In Poland, patches of Eleocharito-Caricetum bohemicae are mainly observed in habitats of anthropogenic origin. Until now, patches of this association have been recorded only on beds of drained fish ponds (less than 100 relevés are available). In most fish ponds intensive fish farming is carried out and they remain flooded over a major part of the year. Water shortage or pond restructuring is often a reason of them being drained for a longer period, thus enabling this association to develop. Considering that in the past the characteristic taxa of this assemblage occurred also in natural habitats, i.e. on river banks, old river-beds, lakes, in depressions, etc., a hypothesis was proposed that habitat changes during the 20th century (in particular regulation of river banks) might have brought about the disappearance of Eleocharito-Caricetum in natural habitats (PopIELA 1997, 2005). This might result in the association occurring at present (perhaps as a 'relic') only in old, extensive complexes of fish ponds where similar conditions occur as in a river (temporary changes of water level).

In Janikowo, in the vicinity of Łęknica, floristically very similar patches with Elatine hexandra were observed 12 years ago (see Popiela 1996), i.e. in the

Table 1. Eleocharito-Caricetum bohemicae Klika 1935

\begin{tabular}{|c|c|c|c|c|c|c|c|c|c|c|c|c|c|c|c|c|c|c|c|}
\hline Successive no. of relevé & 1 & 2 & 3 & 4 & 5 & 6 & 7 & 8 & 9 & 10 & 11 & 12 & 13 & 14 & 15 & 16 & 17 & 18 & 19 \\
\hline Vegetation cover [\%] & 80 & 70 & 60 & 70 & 70 & 90 & 90 & 90 & 90 & 90 & 90 & 90 & 80 & 90 & 60 & 60 & 50 & 50 & 80 \\
\hline Localities of relevés & $\mathrm{J}$ & $\mathrm{J}$ & $\mathrm{J}$ & $\mathrm{J}$ & $\mathrm{J}$ & $\mathrm{J}$ & $\mathrm{J}$ & $\mathrm{B}$ & $\mathrm{B}$ & $\mathrm{B}$ & $\mathrm{B}$ & $\mathrm{K}$ & $\mathrm{K}$ & $\mathrm{K}$ & $\mathrm{K}$ & $\mathrm{K}$ & $\mathrm{K}$ & $\mathrm{K}$ & $\mathrm{K}$ \\
\hline \multicolumn{20}{|c|}{ Ch. Eleocharito-Caricetum bohemicae, Cyperetalia fusci, Isoëto-Nanojucetea } \\
\hline Elatine hexandra & . & . & + & 1 & 1 & 3 & 3 & . & . & . & . & . & . & . & . & . & . & $\cdot$ & . \\
\hline Elatine hydropiper & . & . & . & . & . & . & . & . & . & . & . & 4 & 4 & 4 & 3 & 3 & 3 & 3 & 2 \\
\hline Eleocharis ovata & + & + & . & . & . & . & . & + & + & + & . & . & . & . & . & . & . & . & . \\
\hline Carex bohemica & & & & & & & & 1 & 3 & 2 & 2 & . & . & . & . & . & . & . & . \\
\hline Eleocharis acicularis & + & 4 & 2 & 3 & 3 & 4 & 4 & 5 & 4 & 4 & 4 & 3 & 3 & 5 & 1 & + & + & + & 5 \\
\hline Gnaphalium uliginosum & + & + & . & $\cdot$ & 2 & + & $\cdot$ & + & . & . & 1 & . & . & . & . & . & . & . & . \\
\hline Juncus bufonius & . & . & . & . & . & . & 1 & 2 & 4 & 3 & 2 & . & . & . & . & . & . & . & . \\
\hline Cyperus fuscus & & & & & & & & 2 & 1 & 2 & 3 & . & . & . & . & . & . & . & . \\
\hline \multicolumn{20}{|l|}{ Other species } \\
\hline Juncus articulatus & . & 1 & + & + & + & + & 1 & 2 & 2 & 2 & 1 & . & + & + & . & + & + & . & + \\
\hline Juncus bulbosus & . & 1 & 2 & 3 & 3 & + & 3 & $\cdot$ & $\cdot$ & . & . & . & . & . & . & . & . & $\cdot$ & . \\
\hline Oenanthe aquatica & + & 1 & 1 & + & + & . & + & + & + & + & + & . & . & . & . & . & . & . & . \\
\hline Ranunculus flammula & . & + & 1 & 2 & 2 & . & . & . & . & . & . & . & . & . & . & . & • & . & . \\
\hline Callitriche cophocarpa & . & 1 & + & + & + & . & + & . & . & . & . & 2 & 1 & + & 2 & + & 1 & + & + \\
\hline Alisma plantago-aquatica & + & . & + & . & 1 & + & . & . & . & + & + & + & + & . & . & . & + & . & . \\
\hline Lysimachia vulgaris & . & . & + & . & . & . & . & + & + & + & . & & ${ }^{\circ}$ & . & . & . & . & ${ }^{\circ}$ & . \\
\hline Equisetum fluviatile & + & . & . & . & . & . & . & . & . & . & . & 2 & + & . & . & . & . & . & + \\
\hline Veronica beccabunga & . & . & . & . & . & . & . & . & . & . & . & + & + & + & + & + & + & + & + \\
\hline Polygonum nodosum & 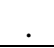 & . & . & . & . & . & . & . & . & . & . & + & . & + & . & . & + & . & + \\
\hline
\end{tabular}

Sporadic species: Berula erecta 19, Galium palustre 2, 3, 4, Juncus tenuis 10, Lycopus europaeus 8, Mentha aquatica 2, 7, Polygonum nodosum 7, Potamogeton natans 1, 3, 4, Ranunculus scelerathus 9, 10, 11, Rorippa palustris 1, 2, Sagittaria sagittofolia 2, Scirpus sp. 11, Stellaria palutris 2, 3

Explanations: J - Janików, B - Brody, $\mathrm{K}$ - Lake Kwiecko; the area of the relevés ranged from 0.4 to $2.0 \mathrm{~m}^{2}$ 


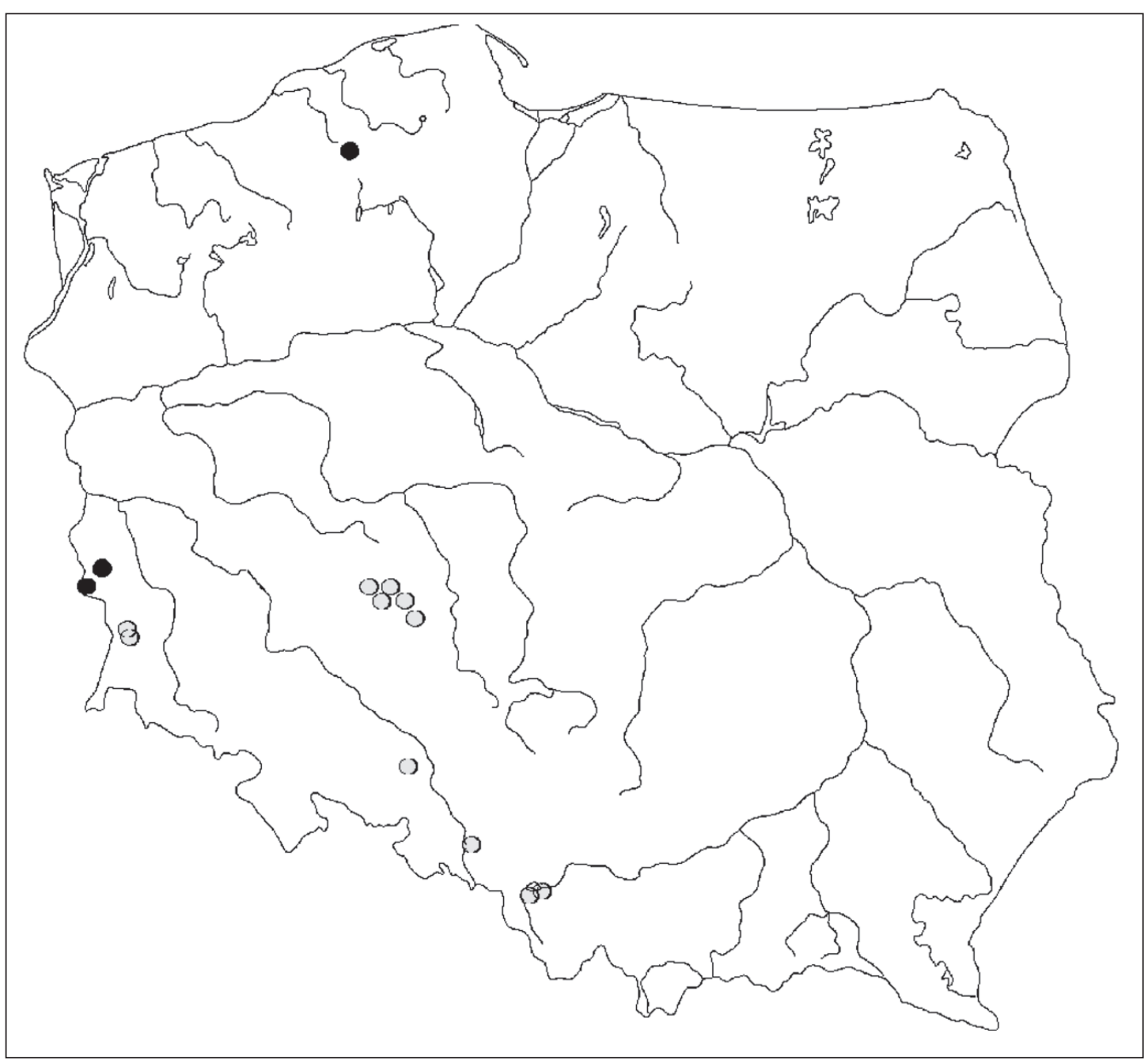

Fig. 1. Eleocharito-Caricetum bohemicae in Poland (after PopIELA 1997, changed). The black points show localities discussed

same complex as today, but on the bed of another fish pond. It may be assumed that a seed bank is likely to be found in the mud of most ponds in this area, allowing the development of the community under discussion in case favourable conditions arise. Many papers stress a particular importance of a durable permanent seed bank in soil for the development of communities of the IsoëtoNanojuncetea class, showing that seeds preserve germination ability over decades (see DeIL 2005 and references cited there).

The Eleocharo-Caricetum bohemicae patches documented in this study are phytocenoses of this association observed on the absolute limits of the distribution range of this syntaxon. Relevés with Eleocharis ovata and Carex bohemica from the locality in Brody document the Eleocharo-Caricetum bohemicae patches situated northernmost in Poland, whereas those from Lake Kwiecko - the easternmost ones. The latter developed on the bed of a lake, the waters of which are used in a pumped-storage power station, thus its bed is periodically drained, similarly as it happens in fish ponds (see
ŚPIEWAKOWSKI \& KoRCZYŃSKI 1993). Moreover, they are the first documented phytocenoses of EleocharitoCaricetum ovatae which developed in a habitat other than beds of drained fish ponds. The association is distinguished in Poland by the presence of at least one of the characteristic taxa (Carex bohemica, Eleocharis ovata, Elatine hexandra, E. hydropiper, E. triandra and Lindernia procumbens) and a high constancy of Eleocharis acicularis, Limosella aquatica and Riccia cavernosa as well as the absence of Juncus bufonius and Plantago intermedia (PopIELA 1999).

In the patches described in this paper, out of the above-mentioned ones four species characteristic of this association were reported, of which three, i.e. Elatine hexandra, E. hydropiper and Eleocharis ovata, are taxa rarely observed in Central Europe, found in the locations under discussion on the northeastern periphery of their general distribution range (Elatine hexandra and Eleocharis ovata) or on the limits of regional disjunctions (Elatine hydropiper) (Figs 2-4). 


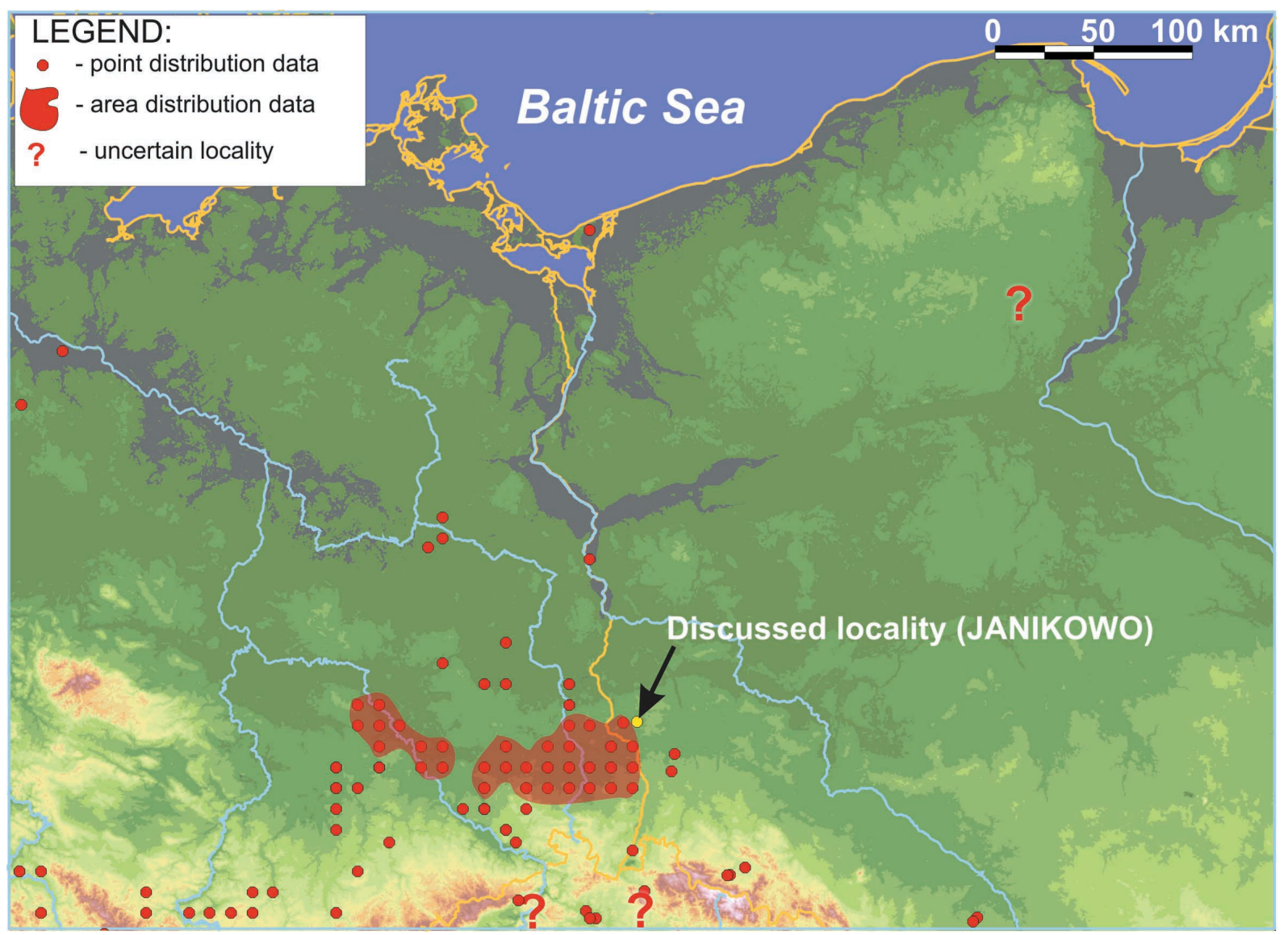

Fig. 2. Distribution of Elatine hexandra L. in Central Europe (oryg.). The arrow shows the locality discussed (Janikowo)

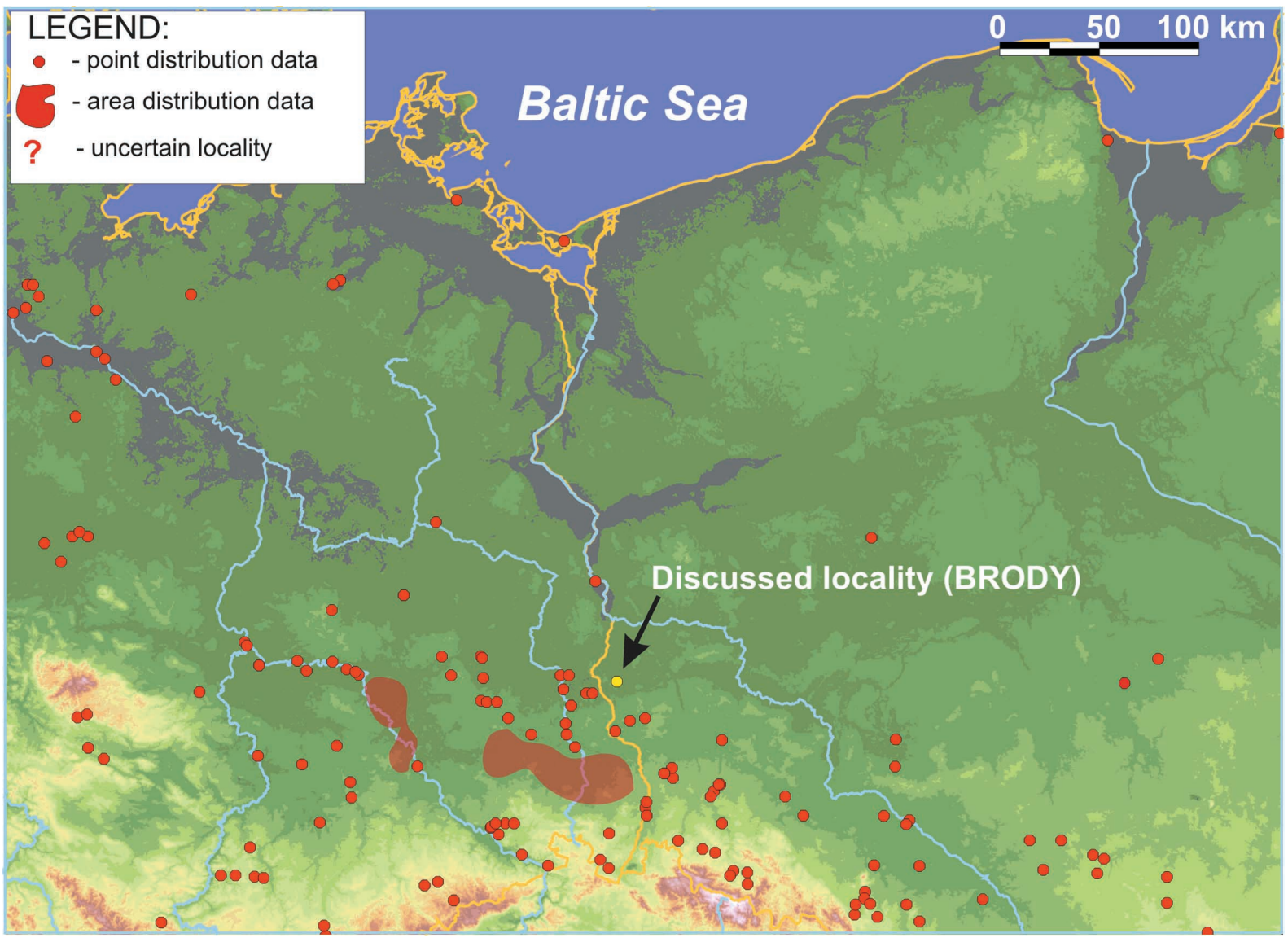

Fig. 3. Distribution of Eleocharis ovata L. in Central Europe (oryg.). The arrow shows the locality discussed (Brody) 


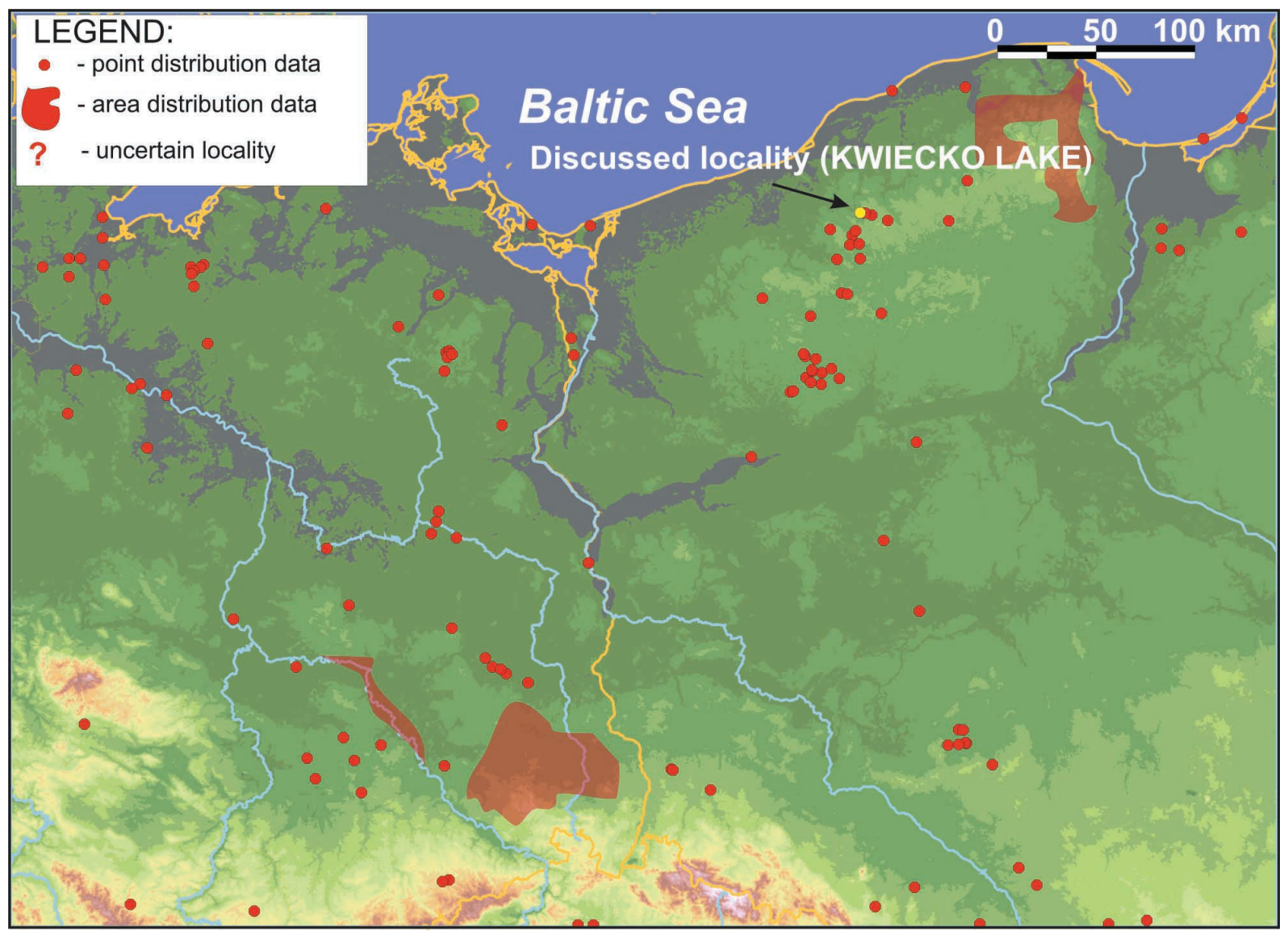

Fig. 4. Distribution of Elatine hydropiper L. in Central Europe (oryg.). The arrow shows the locality discussed (Lake Kwiecko)

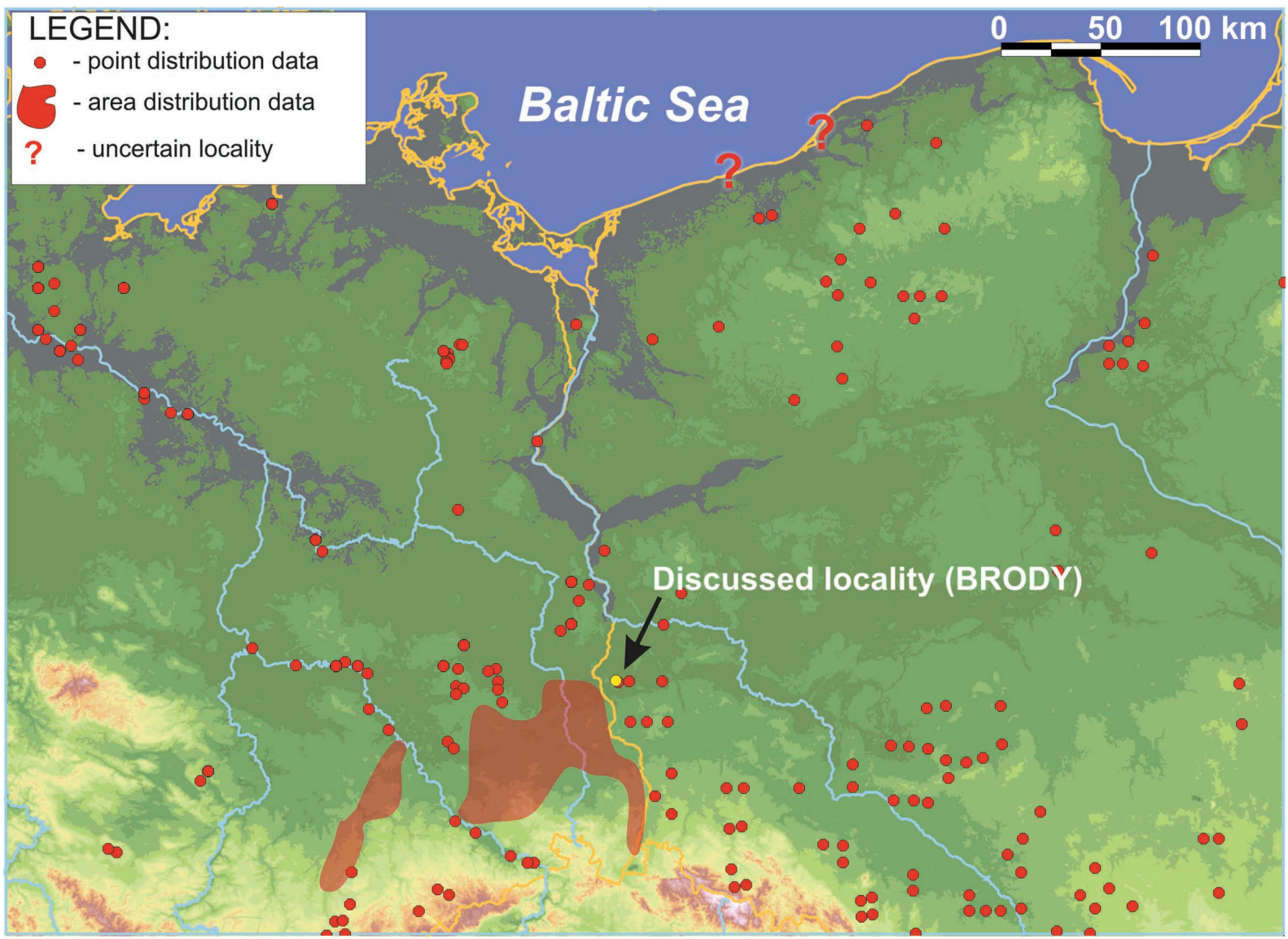

Fig. 5. Distribution of Carex bohemica L. in Central Europe (oryg.). The arrow shows the locality discussed (Brody) 


\section{Conclusions}

Phytosociological data presented in this paper, classified into Eleocharo-Caricetum bohemicae, are easternand northernmost phytocenoses of this assemblage described in Central Europe. The eastern limits of the distribution range of this association overlap with the eastern periphery of occurrence of its characteristic species; they are absolute limits (in case of Eleocharis ovata and Elatine hexandra), or the eastern periphery of the home range - as in case of Elatine hydropiper - or the limits of the continuous distribution range (Carex bohemica). With reference to the two latter species, it should be stressed that many points marked on the distribution maps (Figs. 4 and 5) are historical sites. The data for Lake Kwiecko are the only one site of Elatine hydropiper existing at present in the western and central part of Pomerania.

Acknowledgements. Scientific work financed from the resources earmarked for science as the Research Project no. $\mathrm{PO} 4 \mathrm{C} 03525$.

\section{References}

Benkert D., Fukarek F. \& Korsch H. 1996.Verbreitungsatlas der Farn- und Blütenpflanzen Ostdeutschlands. 615 pp. Gustav Fischer Verlag, Jena.

Brullo S. \& Minissale P. 1998. Considerazioni sintassonomiche sulla classe Isoëto-Nanojuncetea. Itinera Geobotanica 11: 263-290.

DEIL U. 2005. A review on habitats, plant traits and vegetation of ephemeral wetlands - a global perspective. Phytocoenologia 35(2-3): 533-705.

Fukarek F. \& Henker H. (eds.). 2006. Flora von Mecklenburg-Vorpommern. Herausgegeben von $\mathrm{H}$. Henker \& Ch. Berg, Weissdornverlag Jena.

Haeupler H. \& SchöNFelder P. 1988. Atlas der Farn und Blütenpflanzen der Bundesrepublik Deutschland. 768 pp. Verlag Eugen Ulmer, Stuttgart.

v. LAmpe M. 1996. Wuchsform, Wuchsrhythmus und Verbreitung der Arten der Zwergbinsengesellschaften. Dissertationes Botanicae 226: 1-353.

Mirek Z., Pięroś-Mirkowa H., Zając A. \& Zając M. 2002. Flowering plants and pteridophytes of Poland. A checklist. In: Z. MireK (ed.). Biodiversity of Poland 1, 442 pp. W. Szafer Institute of Botany, Polish Academy of Sciences, Kraków.

PopielA A. 1996. Zbiorowiska z klasy Isoëto-Nanojuncetea na terenie Polski Zachodniej. Fragm. Flor. Geobot. Polonica 3: 289-310.
Popiela A. 1997. Zbiorowiska namułkowe z klasy Isoëto-Nanojuncetea Br. Br. et Tx. 1943 w Polsce. Monogr. Bot. 80: 1-59.

Popiela A. 1998. Nowe stanowiska gatunków z rodzaju Elatine L. w Polsce. Bad. Fizjogr. Pol. Zach. seria BBotanika 47: 257-264.

Popiela A. 1999. Communities and species of IsoëtoNanojuncetea in Poland - syntaxonomic classification, distribution and current state of research. Mitt. bad. Landesver. Naturkunde u. Naturschutz N.F. 17(2): 369-380.

Popiela A. 2001. Carex bohemica, Elatine hexandra, E. hydropiper, Eleocharis ovata. In: A. ZAJĄC \& M. ZAJAC (eds.). Distribution Atlas of Vascular Plants in Poland. Edited by Laboratory of Computer Chorology, Institute of Botany, Jagiellonian University, Cracow.

Popiela A. 2005. Isoëto-Nanojuncetea species and plant communities occurring on their eastern distribution range (Poland). Phytocoenologia: 35(2-3): 283-303.

SLAVík B. 1990. Fytokartografické syntézy ČSR. Phytogeographical syntheses of the ČSR. 2, 179 p. Botanický ústav ČSAV. Botanical Institute of Czechoslovak Academy of Science Pruhonice.

ŚPIEWAKOwSKi E. R. \& KorCZYŃski M. 1993. Wpływ elektrowni w Żydowie na dynamikę przemian flory Jezior Kamienno i Kwiecko oraz ich stref zalewowych. Fragm. Flor. Geobot. Polonica 38(1): 303-318. 